\title{
Katarzyna Sadowska
}

\section{Dobrostan psychiczny dziecka w procesie edukacji szkolnej w czasach pandemii}

\section{Mental Well-being of a Child in the Process of School Education in Times of the Pandemic}

\section{SŁOWA KLUCZE ABSTRAKT}

dobrostan Celem opracowania jest podjęcie namysłu nad dobrostanem psychiczpsychiczny, dziecko, nym dziecka funkcjonującego w procesie edukacji szkolnej w czasach edukacja, szkoła, pandemii. W artykule odnajdujemy teoretyczne rozważania na temat edukacja w czasach pojęcia dobrostanu psychicznego, syntetyczną analizę funkcjonowania pandemii systemu edukacji szkolnej, szczególnie w okresie pandemii Covid-19. Celem badań autorki jest zweryfikowanie poczucia dobrostanu psychicznego dzieci w procesie ich uczestnictwa w zdalnej edukacji szkolnej, zaś problem badawczy zawarty został w pytaniu: w jakim stopniu dziecko będące uczestnikiem szkolnej edukacji zdalnej odczuwa satysfakcję z procesu własnej edukacji, własnej aktywności, zaistniałego stanu rzeczy? W trakcie analizy zebranego materiału badawczego podjęto próbę odpowiedzi na pytanie, ukazując różnorodne konteksty funkcjonowania ucznia w procesie nauczania zdalnego.

\section{KEYWORDS ABSTRACT}

menta well-being, child, education, school, education in times of pandemic
The aim of the study is to reflect on the mental well-being of a child functioning in the process of school education in times of the pandemic. The article presents theoretical considerations on the concept of mental well-being, and a synthetic analysis of the functioning of 
the school education system, especially during the Covid-19 pandemic. The aim of the author's research is to verify the sense of mental well-being of children in the process of their participation in remote school education, and the research problem is the question: to what extent does a child participating in remote school education feel satisfied with the process of their own education, their own activity, and the existing state of affairs? During the analysis of the collected research material, the author attempts to answer the question by showing various contexts of the student's functioning in the process of online learning.

\section{Dobrostan psychiczny i sytuacja współczesnej szkoły}

Sięgając do literatury na temat dobrostanu psychicznego, można dostrzec, iż jego koncepcja wywodzi się w dużym stopniu z dwóch perspektyw: klinicznej, w której na centralnym miejscu stawiano zdrowie, oraz z perspektywy psychologicznej, która z kolei zwracała uwagę na nastrój i emocje. Zgodnie z tradycją kliniczną, dobrostan oznacza „nieobecność negatywnych objawów/stanów takich jak: dystres, depresja, niepokój, obawy itp." (Ilska, Kołodziej-Zaleska 2018: 156).

W związku z postępem w badaniach nad dobrostanem psychicznym człowieka pojawiły się jednak wątpliwości w zakresie tego, czy nieobecność negatywnych emocji jest równoznaczna z poczuciem szczęścia. W latach 90. XX wieku pojęciem dobrostanu psychicznego zajął się m. in. Martin E. P. Seligman (w ramach nurtu psychologii pozytywnej) (Seligman 1993, 2002, 2011). Uznał on, iż warunkiem poczucia dobrostanu jest przede wszystkim poczucie sprawstwa - posiadanie i wykorzystanie zasobów, „które towarzyszą działaniu człowieka zmierzającego do aktualizacji własnego potencjału, a także życiu spójnemu i zgodnemu z prawdziwym Ja” (Cieślińska 2013: 100). Definicja Seligmana wydaje się korespondować z aktualną koncepcją WHO, którą przywołują Karolina Kossakowska i Magdalena Zadworna: „jakość życia to subiektywne postrzeganie przez jednostkę jej pozycji w życiu w relacji do jej celów, oczekiwań, standardów i zainteresowań" (Kossakowska, Zadworna 2019: 223). Badaczki zaznaczają, że pojęcia takie jak: dobrostan psychiczny, szczęście, jakość życia, satysfakcja, czy zadowolenie z życia uznaje się często za bliskoznaczne (Kossakowska, Zadworna 2019: 223). Dobrostan - na gruncie psychologii pozytywnej - jest pojęciem odnoszącym się do korzystnych elementów sytuacji, w których znajduje się człowiek w ciągu swego życia (Trzebińska 2008: 39).

Pomimo iż pojęcie dobrostanu psychicznego próbowano zdefiniować wielokrotnie, dookreślenie tegoż przysparza wielu dylematów - każdy z nas w nieco inny sposób definiować będzie nie tylko „szczęście” czy „satysfakcję”, ale inaczej określi także cechy tzw. życia optymalnej jakości (King, Eells, Burton 2007). Kossakowska i Zadworna, 
odnosząc się do dorobku dwóch nurtów filozoficznych: hedonistycznego i eudajmonistycznego, podają, że w ramach pierwszego „dobrostan” definiuje się jako pozytywny stan psychiczny, który przejawia się wysokim poziomem satysfakcji z życia i jego różnych obszarów, charakteryzuje się przewagą uczuć pozytywnych nad negatywnymi oraz „uogólnionym poczuciem szczęścia” (Kossakowska, Zadworna 2019: 223). Koncepcja Seligmana wpisuje się w nurt eudajmonistyczny rozumienia dobrostanu psychicznego, bowiem wysoka jakość życia wynika z poczucia sprawstwa i autonomii człowieka, rozwoju, samorealizacji, zaangażowania. W badaniach nad dobrostanem wyłaniają się zatem dwie orientacje badawcze: hedonistyczna, która zajmuje się szczęściem człowieka rozumianym jako przyjemność i zadowolenie, oraz eudajmonistyczna - koncentrująca się wokół problemu potencjału jednostki ludzkiej i uznająca za życie wysokiej jakości życie pożyteczne i sensowne (Ilska, Zaleska 2018: 157).

Współczesny świat wydaje się nie blokować możliwości w zakresie samorealizacji jednostki, wymusza wręcz obwiązek ustawicznej edukacji i promuje edukację całożyciową. Człowiek XXI wieku inwestuje w rozwój, ma możliwość samodoskonalenia, ma prawo samostanowienia.

Szczególnym miejscem, w którym młody człowiek powinien odkrywać i utrwalać własny potencjał oraz czerpać satysfakcję z własnej aktywności, jest szkoła, która jawi się często jako miejsce niesprzyjające poczuciu dobrostanu. Już sam fakt „obowiązku szkolnego” (a nie np. „obowiązku nauki”) sprowadza szkołę do czegoś nieuchronnego. Choć od wielu lat pedagodzy postulują zmiany w systemie edukacji, namawiają do porzucenia „programocentryzmu” na rzecz koncepcji „dziecka w centrum”, zmiany, które obserwujemy, nadal nie są wystarczające. Dobrostan psychiczny przeciętnego ucznia zostaje nadszarpnięty nawet kilka razy w ciągu tygodnia, a pełne entuzjazmu dziecko gaśnie, bowiem dowiaduje się często, czego nie potrafi: „nie potrafię czytać”, „brzydko piszę”, „Pani powiedziała, że się nie staram, choć się bardzo starałem”, „nie zdążyłem przepisać z tablicy”, „bałem się powiedzieć przy wszystkich, że nie zdążyłem przepisać”, „nie zdążyłem nic zjeść, bo musiałem się spakować, a powinniśmy jeść szybko, bo Pani mówi, że nie zdążymy”, „dostałem F bo nie przyniosłem nożyczek i Pani powiedziała, że nie jestem przygotowany do lekcji”'. Tego typu wypowiedzi dzieci w wieku wczesnoszkolnym można niestety mnożyć. Trudno nie postulować więc za Seligmanem „rewolucji w światowej edukacji”, o której od wielu lat piszą także polscy wybitni pedagodzy (Śliwerski, Śliwerska, Śliwerski 1993; Śliwerski 2007, 2009, 2015; Klus-Stańska, Nowicka 2019; Klus-Stańska 2010, 2015).

\footnotetext{
Są to autentyczne wypowiedzi dzieci z klas 1-3, zebrane w latach 2017-2020 wśród uczniów jednej z poznańskich szkół podstawowych, do której uczęszcza w sumie około 1000 uczniów, a edukacja w drugiej klasie z tego względu jest edukacją na tzw. drugą zmianę.
} 
Edukacja umożliwiająca poczucie sprawstwa, szczęścia, satysfakcji z własnej aktywności, mieści się m.in. w definicji alfabetyzacji naukowej, której Barbara Surma poświęca 14. tom „Edukacji Elementarnej w Teorii i Praktyce”, zaznaczając szczególną wagę tejże alfabetyzacji już na etapie przedszkola (Surma 2019: 7-8). Redaktor naczelna podkreśla, iż alfabetyzacja naukowa jest umiejętnością zaangażowania się w rozumienie i zdobywanie wiedzy w refleksyjny sposób, dodatkowo w sposób umożliwiający budowanie świadomości naukowej człowieka w przestrzeni pozwalającej na osiagganie przez niego satysfakcji osobistej i radości z własnej aktywności poznawczej (Surma 2019: 7-8).

Edukację koncentrującą się na podnoszeniu poziomu satysfakcji z życia szkolnego dziecka opisuje m.in. Krystyna Chałas, która proponuje edukację aksjologiczną, dydaktykę zaangażowaną i wychowanie ku wartościom (Chałas 2018, 2020). Autorka przekonuje, że edukacja to „wspomaganie wychowanków w urzeczywistnianiu własnej, lecz właściwej hierarchii wartości, prowadzącej do integralnego rozwoju, do pełni człowieczeństwa..." (Chałas 2018: 12). Integralny rozwój osoby ucznia należy więc traktować jako nadrzędny cel szkoły (Chałas 2020: 113). Tymczasem szkoła opiera się „na pasterskiej relacji pomiędzy personelem instytucji edukacyjnej a uczęszczającymi do niej dziećmi; relacji opartej na zasadzie odpowiedzialności pasterza za dobro stada, co z kolei zakłada podporządkowanie stada pasterzowi” (Gawlicz 2008: 38), a zasadą powszechnego kształcenia jest normalizacja (Foucault 1998: 180). Pytanie współczesnego ucznia brzmi zatem nader często: czy przyjąć gorset normalności, czy się rozwijać w zgodzie ze sobą tak, aby osiągnąć dobrostan psychiczny?

\section{Edukacja szkolna w czasach pandemii}

Edukacja szkolna w czasach pandemii jest edukacją zdalną lub hybrydową. Badania zrealizowane wśród uczniów szkół podstawowych na terenie całego kraju w 2020 roku przez zespół ekspertów z Uniwersytetu Warszawskiego prowadzą do wniosku, że dzieci i młodzież, pomimo kłopotów technicznych, poradziły sobie „dobrze z wyzwaniem nauki na odległość”, jednak „całościowa ocena wystawiona pedagogom przez uczniów za prowadzenie edukacji zdalnej nie jest ... jednak wysoka” (Plebańska, Szyller, Sieńczewska 2020: 35-36).

Biorąc pod uwagę wypowiedzi nauczycieli, których wysłuchałam pod koniec roku szkolnego 2019/ 2020, dostrzegłam, że ich główną troską w sytuacji edukacji zdalnej była pełna realizacja podstawy programowej ${ }^{2}$. Rodzice zmartwieni z kolei byli klasyfikacją końcową dzieci, mobilizowali się więc codziennie do sprawdzania informacji

\footnotetext{
2 Wniosek ten wynika z rozmów z nauczycielami realizowanych pod koniec roku szkolnego 2019/2020 na terenie kilku wielooddziałowych poznańskich szkół podstawowych.
} 
zamieszczanych w dzienniku elektronicznym, dostosowywali się do pisemnie wyrażonych i zamieszczonych przez nauczycieli w sieci wytycznych, także do zwrotnego przesyłania skanów ilustrujących wykonane przez dzieci zadania itp.

Słowo „zadanie” w czasach pandemii (w semestrze letnim 2020 r.) nabrało nowego ciężaru gatunkowego (por. Jagielska 2020: 113-114). Analizując obserwowany stan rzeczy, miałam wrażenie, że realizacja podstawy programowej polegała w dużej mierze na wysyłaniu przez nauczycieli informacji o konieczności wykonania „zadania” wraz ze wskazaniem terminu wysyłki zwrotnej. Sytuacja w roku szkolnym 2020/2021 uległa wprawdzie poprawie, jednak nadal wiele osób nauczanie zdalne definiowało jako przesyłanie informacji o potrzebie wykonania zadania i dokonania zwrotu tegoż (wypełnionego) zadania. Sytuacja taka miała miejsce w wielu poznańskich placówkach, a nauczanie synchroniczne nie odbywało się na zasadzie obowiązkowego, ponieważ „nie było regulacji prawnej nakazującej nauczycielowi realizację zajęć w czasie rzeczywistym"3.

\section{Metodologia badań własnych - procedura badawcza}

Przedmiotem badań uczyniłam ogólne poczucie dobrostanu psychicznego dziecka w procesie szkolnej edukacji zdalnej. Przyjęłam, iż dobrostan psychiczny dziecka (zmienna globalna) odnosi się do odczuwania przez dziecko stanu zaspokojenia bądź deficytu jego podstawowych potrzeb (zgodnie z koncepcją psychologii pozytywnej określonych korzystnych i potrzebnych rozwojowo elementów sytuacji, w których funkcjonuje dziecko). Przyjęłam założenie, że elementy te powinny wystąpić, by edukacja zdalna była edukacją efektywną, satysfakcjonującą, a więc taką, która wyzwala i utrwala zasoby dziecka. Elementy te będą zatem wiązały się z następującymi wskaźnikami:

poczucie bieżącej kontroli planu lekcji związanej z przekonaniem o możliwości monitorowania przebiegu organizacji kształcenia zdalnego wraz z poczuciem bezpieczeństwa w zakresie możliwości efektywnej realizacji obowiązku szkolnego;

- poczucie bezpieczeństwa emocjonalnego w kontaktach z nauczycielem i społecznością szkoły;

- poczucie możliwości otrzymania indywidualnego i spersonalizowanego wsparcia emocjonalnego ze strony nauczyciela w kontekście osobistych doświadczeń związanych z zagrożeniem zdrowia i życia najbliższych wynikających z pandemii Covid-19, a wynikające z wychowawczej, opiekuńczej oraz kompensacyjnej funkcji szkoły;

$3 \quad$ Wypowiedź jednego z poznańskich dyrektorów. 
odczuwanie satysfakcji z przyrostu osobistych kompetencji i samorealizacji.

Celem badań było zweryfikowanie poczucia dobrostanu psychicznego dzieci wynikającego z uczestnictwa w zdalnej edukacji szkolnej w opiniach rodziców uczniów, zaś problem badawczy zawarty został w pytaniu: w jakim stopniu dziecko będące uczestnikiem szkolnej edukacji zdalnej odczuwa satysfakcję z procesu własnej edukacji?

Badanie - przy zastosowaniu metody sondażu diagnostycznego - przeprowadzono za pośrednictwem ankiety, przy użyciu kwestionariusza ankiety. Rodzicom zadano następujące pytania:

- Czy Państwa dziecko ma poczucie kontroli planu lekcji i poczucie bezpieczeństwa wiążące się z przekonaniem o „byciu na bieżąco” z obowiązkami szkolnymi? Proszę o uzasadnienie odpowiedzi;

- Czy Państwa dziecko ma możliwość indywidualnej rozmowy lub konsultacji z nauczycielem? Proszę o rozwinięcie wypowiedzi o obserwacje rodzicielskie;

- Czy Państwa dziecko utrzymuje pozytywne relacje z rówieśnikami, pomimo iż ze względu na pandemię są one często ograniczone do kontaktów zdalnych? Proszę o rozwinięcie wypowiedzi;

- Czy Państwa dziecko odczuło ze strony nauczyciela troskę o własne zdrowie i o zdrowie najbliższych? Czy nauczyciele pytają dziecko o samopoczucie i rozmawiają o pandemii? Proszę o rozwinięcie wypowiedzi;

- Czy Państwa dziecko ma osobiste poczucie satysfakcji i zadowolenia z osiąganych przez nie sukcesów w edukacji szkolnej? Proszę o uzasadnienie opinii.

\section{Charakterystyka terenu badawczego i organizacja badań}

Badanie zrealizowane zostało w okresie od 1 marca 2021 do 30 czerwca 2021 roku. Sondaż diagnostyczny przeprowadzony został w grupie 80 rodziców dzieci uczęszczających do klasy II oraz IV szkoły podstawowej ${ }^{4}$. Respondenci pozyskani zostali z terenu kilku osiedli w Poznaniu, co pozwoliło ostatecznie ustalić, iż badaniem objęto rodziców dzieci uczęszczających do czterech powszechnych i wielooddziałowych szkół podstawowych ${ }^{5}$. Aby dokonać rzetelnej charakterystyki próby badawczej, należy zaznaczyć, że:

Dobór poziomu edukacji był poniekąd celowy, bowiem dzieci w klasie drugiej posiadały już pewne doświadczenia szkolne, a ich rodzice wdrożeni byli w proces wspierania dziecka w nauce szkolnej. W przypadku doboru rodziców dzieci uczęszczających do klasy IV, miałam na uwadze fakt nowego wyzwania edukacyjnego dla doświadczonych już obowiązkiem szkolnym dzieci. Cytowane wypowiedzi respondentów podaję w formie oryginalnej.

5 Ponieważ celem badań było zweryfikowanie poczucia dobrostanu psychicznego dzieci wynikającego z uczestnictwa w zdalnej edukacji szkolnej w opiniach rodziców uczniów, nie poszukiwano korelacji pomiędzy zmiennymi niezależnymi respondentów takimi jak wiek, płeć, wykonywany zawód itp., 
54 respondentów to osoby pomiędzy 25. a 35. rokiem życia;

- 26 respondentów to osoby powyżej 35 . roku życia;

- w badaniu udział wzięło 66 kobiet i 14 mężczyzn;

- 68 osób zadeklarowało, że ich dzieci objęte są edukacją wczesnoszkolną;

- 12 osób określiło siebie jako rodziców dzieci uczęszczających do klasy IV.

\section{Analiza wyników badań}

Rodzice, diagnozując poziom zadowolenia ich dzieci z edukacji zdalnej, w pierwszej kolejności zwrócili uwagę na niekonsekwencję grona pedagogicznego w zakresie ujednolicenia kontaktów z dziećmi w ramach obowiązującego planu lekcji. Brak tego ujednolicenia wiązał się, zdaniem 72 respondentów, z brakiem poczucia bezpieczeństwa dziecka oraz lękiem przed ewentualnymi „zaległościami” i spóźnieniami. Aż 70 rodziców zaznaczyło, że nauczanie zdalne powinno oznaczać obowiązkowe łączenie się nauczyciela z dziećmi zgodnie z planem lekcji. 72 interlokutorów uznało, że ich dziecko nie miało poczucia kontroli nad obowiązującym je planem lekcji, co często wiązało się z frustracją i obawą przed złą oceną, powodowało także stałą dezorganizację przedpołudnia.

Wśród odpowiedzi respondentów, zarówno rodziców ośmiolatków, jak i dzieci w jedenastym roku życia, wyłaniają się dwie kategorie krytycznych sądów. I kategoria wypowiedzi obejmuje przekonania rodziców (45 osób) o braku poczucia przez dziecko kontroli nad planem lekcji, którego konsekwencją jest deficyt w zakresie odczuwania przez dziecko dobrostanu psychicznego. W ramach I kategorii wypowiedzi respondenci zgłaszali, iż: „ponad godzinna przerwa w połączniu z nauczycielem w trakcie dnia skutkuje dezorganizacją aktywności dziecka, nie potrafi ono precyzyjnie określić godziny i zajęte zabawą nie pamięta, że powinno się ponownie połączyć"; „to, że dziecko nie ma zajęć wf lub, że Pan przesyła filmik do obejrzenia skutkuje tym, że syn nie wraca na kolejną lekcję na czas”; „córce jest trudno samodzielnie określić czas przerwy zarządzonej pomiędzy lekcjami, co sprawia, że dziecko ma obawy, że się spóźni”; „ponieważ niektóre lekcje nie odbywają się na teamsie, dziecko odchodzi od komputera i zapomina ponownie się połączyć”; „nauczyciel wysyła kartę pracy i oczekuje zwrotu do określonej godziny, a córka nie potrafi samodzielnie wysyłać skanów na czas, co sprawia, że bardzo się stresuje”; „w przerwie pomiędzy językiem polskim

a wyrażonymi przez respondentów opiniami na temat dobrostanu psychicznego ich dzieci. Ponieważ potencjalnym respondentom rozdano 120 kwestionariuszy, a otrzymano zwrotnie zaledwie $80 \mathrm{z}$ nich, badacz wyszedł z założenia, że każdy rodzic biorący aktywny udział w badaniu charakteryzuje się troską o umożliwienie dziecku realizacji obowiązku szkolnego, charakteryzuje się nadto niepokojem o stan edukacji zdalnej w kontekście potrzeb i możliwości własnego dziecka. 
i matematyką jest muzyka, podczas której Pani wysyła zadanie. Syn nie jest w stanie samodzielnie wykonać zadania z pisania nut, więc konsekwentnie unika czytania wiadomości od pani z muzyki”, itp.

II kategoria wypowiedzi obejmuje przekonania o nieuzasadnionym i niepotrzebnym obciążaniu dzieci odpowiedzialnością za cudze nieobecności i kłopoty w zakresie nawiązania połączenia. W ramach tej kategorii wyróżnić można m.in. następujące opinie: „córka ma poczucie dyskomfortu, gdy nauczyciel każe im przekazać innym dzieciom, by się połączyły, ponieważ jeśli tego nie zrobią wstawi im jedynkę za brak możliwości odpytania”; „sprawiedliwość musi być - nauczyciel wstawia jedynki osobom, które nie połączą się na początku lekcji zakładając, że robią to celowo, by uniknąć wywołania do odpowiedzi i informuje o swoim przekonaniu całą klasę”; „nauczycielka prosi, by dzieci przekazały nieobecnym informację, że wpisała im nieprzygotowanie” itp.

W związku z poczuciem dyskomfortu dzieci związanym z niekonsekwencją grona pedagogicznego w zakresie form kształcenia na odległość, większość rodziców (72 osoby) wyraziła przekonanie, że nauczanie zdalne, dla dobra emocjonalnego ich dzieci, powinno być nauczaniem synchronicznym.

Odpowiadając na pytanie dotyczące tworzenia przez nauczycieli przestrzeni do indywidualnej rozmowy z dzieckiem, większość rodziców odpowiedziała przecząco (74 osoby). Rodzice wyrażali przekonanie, że nauczyciele - poza wychowawcami - nie byli nadmiernie zainteresowani emocjami swych uczniów, a szereg dziecięcych wyjaśnień dotyczących powodów nieobecności lub braku zadania nauczyciele traktowali w kategoriach „wymówek”.

Analiza materiału badawczego pozwoliła na wyłonienie czterech kategorii wypowiedzi respondentów:

I kategoria - zawiera krytyczne sądy na temat indywidualizacji procesu edukacji zdalnej. Zdaniem aż 45 respondentów, nauczyciele koncentrowali się na „programie” i „łapaniu” ocen. Potwierdzają ten fakt opinie wyrażone przez kolejnych 19 rodziców, którzy dodatkowo przyznali, że otrzymali oni w kwietniu informację telefoniczną o tym, że jeśli dziecko nie zrealizuje przesłanych „na dzienniku zadań” (które w przypadku nauczycieli uczących dzieci wspomnianych respondentów równoznacznie uznawane jako realizacja lekcji), dzieci „nie będą klasyfikowane”;

II kategoria wypowiedzi dotyczy rodziców, którzy także nie dostrzegli tworzenia przestrzeni do indywidualnych rozmów, spotkań z dziećmi, zauważyli jednak pewną argumentację nauczycieli w tym zakresie. Rodzice ci (32 osoby) wyrażali żal, iż np. „niektórzy nauczyciele klas 1-3 przekonywali rodziców, że ponieważ dzieci nie mogą wysiedzieć przed monitorem, dużą część zadań muszą realizować w ramach zadań domowych” i dlatego nauczanie synchroniczne „nie ma sensu”; 
III kategoria wypowiedzi - tym razem pozytywnych - pozwala na wyrażenie przekonania, że gdy dzieci nie były obecne z powodu choroby lub towarzyszących rodzinie emocji związanych z hospitalizacją czy śmiercią bliskich, wychowawcy „reagowali przeważnie ze zrozumieniem", jednak nie przekładało się to na tzw. ulgi (72 osoby) ${ }^{6}$;

IV kategoria wypowiedzi zawierała krytyczne sądy związane z brakiem dostrzegania przez nauczyciela dobrych chęci uczniów. Aż 16 rodziców orzekło, że nauczyciele: „czyhają jak gdyby na przyłapanie dzieci na jakimś niemile widzianym zachowaniu”; „najkrótsze rozłączenie się dziecka lub zawieszenie mikrofonu traktują jakby dziecko zrobiło to celowo”; „każą włączać kamery i mikrofony, by dzieci nie kombinowały, a potem denerwują się, że jest za głośno, bo ktoś w domu odkurza”; „dopytują na dzienniku rodzica, czy na pewno zapomniał o wydrukowaniu dziecku zadania, bo dziecko tak powiedziało”; „są przekonani, że dzieci grają w gry na lekcjach, jeśli dzieci nie patrzą prosto w monitor”; „część nauczycieli każe włączyć kamery, a część wręcz nie życzy sobie włączonych kamer", itp.

Wyniki dotyczące zagadnienia związanego z udziałem nauczyciela w utrzymywaniu pozytywnych relacji między rówieśnikami wydają się mocno niepokojące - aż 72 respondentów wyraziło przekonanie, że jakość tychże relacji jest niska, a nauczyciele nie partycypowali w integracji grupy. W ramach odpowiedzi dotyczących omawianego problemu wyszczególnić można dwie kategorie: pierwsza z nich obejmuje sądy na temat form utrzymywania kontaktów, druga zaś zaznacza udział nauczycieli w procesie „integrowania” rówieśników.

I kategoria obejmuje 45 sądów o tym, iż kontakty rówieśnicze w pandemii ograniczają się do wspólnych gier lub interakcji przez internet, np. „kontakty ograniczone są do rozgrywek w grach”; „dzieci integrują się głównie poprzez wspólne gry”. Wyłącznie 12 spośród wspomnianych 45 respondentów zgłosiło, że dzieci dodatkowo spotykały się osobiście, by np. „pograć w piłkę” czy porozmawiać.

II kategoria wypowiedzi zawiera opinie dotyczące nieświadomych, jednak niekorzystnych dla dzieci działań nauczycieli, w tym np. „obciążała dzieci odpowiedzialnością za brak łączności z innymi dziećmi”; „nauczycielka każe dzieciom kontaktować się z córką przez telefon, gdy ma problemy z połączeniem, każe przekazać, że jeśli córka się nie połączy z nauczycielka do określonej godziny otrzyma ocenę niedostateczną za brak odpowiedzi”; „Pani wielokrotnie prosiła inne dzieci, by wysyłały do nieobecnych informację o konieczności połączenia się z nią twierdząc, że nieobecni nie otrzymają pozytywnej oceny z kartkówki bo ich nie ma”, „o nieobecnym chłopcu Pani wyrażała się w niemiły sposób i poinformowała klasę, że powinien - tak jak inni - być, bo skoro ona może, to on także", itp.

$6 \quad$ Pomimo powyżej przytoczonej pozytywnych opinii należy zaznaczyć, że aż 53 rodziców stwierdziło, iż nauczyciele przedmiotów nie interesowali się bieżącym samopoczuciem ich dzieci. 
Wynikiem wyżej opisanych działań nauczycieli są wnioski poczynione w ramach wspomnianej grupy rodziców o narastających animozjach pomiędzy społecznością uczniów. Aż 9 respondentów wyraziło zaniepokojenie, że dzieci podczas lekcji wysyłały sobie niemiłe wiadomości, gdy któreś z nich nie mogło włączyć mikrofonu lub kamery, że uczniowie etykietowali dzieci, które nie dysponowały szybkim łączem.

Ostatnią kategorię wypowiedzi można uznać za kategorię zawierającą pozytywne sądy. Niepokojący jest jednak fakt, że do tej grupy respondentów należy wyłącznie 19 rodziców. W ramach wypowiedzi wspomnianych tu osób można ogólnie uznać, że - zdaniem rodziców - wychowawcy klas ich dzieci starali się pracować nad dobrymi relacjami interpersonalnymi w klasie.

Z uzyskanych danych dotyczących problemu związanego z troską nauczyciela o stan zdrowia dzieci oraz ich rodzin w okresie pandemii wynika, że wyráną troskę w omawianym zakresie wyraziło stosunkowo niewielu nauczycieli (byli to przede wszystkim wychowawcy klas). Zaledwie 15 rodziców zaznaczyło fakt zainteresowania się przez nauczyciela stanem zdrowia ich dziecka oraz stanem poczucia bezpieczeństwa dziecka w obliczu choroby osoby bliskiej. Nauczyciele ci, jak opisywali rodzice, dowiadując się o niekorzystnej sytuacji w środowisku ucznia, dawali „przyzwolenie” na indywidualne „zaliczanie”, nie odpytywali z poprzednich lekcji. Zdarzało się także (3 respondentów), że nauczyciele telefonowali do rodziców dziecka, ustalając z nimi indywidualny plan pracy.

Respondenci zaznaczali, że: „nauczyciel zajmuje się egzekwowaniem zadań domowych”, „realizacją programu”, i tylko „czasem niektórzy nauczyciele pytają o to, czy wszystko u uczniów w porządku, ale nauczyciele ci należą do mniejszości”. Były także pojedyncze głosy, iż: „wychowawca w ogóle nie zareagował na informację o tym, że dziecko ma matkę w szpitalu, nie podjął z dzieckiem rozmowy na temat jego przeżyć”, a "funkcja wychowawcza szkoły sprowadza się do przyznawania i odejmowania dzieciom punktów za ich "dobre i złe uczynki«" itp.

Odpowiadając na pytanie o dostrzeżenie satysfakcji lub radości uczniów z edukacji w okresie nauczania zdalnego, większość rodziców (67 osób) stwierdzała, że nie dostrzegła u dziecka tychże emocji. Wypowiedzi rodziców można ująć w trzy kategorie.

W I kategorii respondenci jako przyczynę braku dziecięcej satysfakcji podawali najczęściej niejednorodną politykę szkoły w zakresie kształcenia zdalnego („czasem synchronicznie, czasem off-line”), wzmiankowali, że ich dziecko ma poczucie „lęku”, „niepewności”; „nie wie, kiedy Pani sprawdza prace, nieraz czeka na ocenę bardzo długo, nieraz jest zdziwione, jak mu mówię, że w dzienniku ma taką czy inną ocenę za coś, o czym dziecko zupełnie nie pamięta”; „kompletnie się nie orientuje w kryteriach oceny”; "nigdy nie wie, co je czeka w kolejnym dniu, bo nauczyciele raz się łączą, a raz się nie łączą”; „wypełniało raz test i nie wiedziało, że to test on-line więc poszło do toalety, a gdy wróciło już miało ocenę dostateczną, bo Pani uznała, że na ostatnie 
pytania syn nie zna odpowiedzi”; ,jedni nauczyciele robią testy i sprawdziany on-line, inni przesyłają je do wypełnienia off-line!”.

II kategoria komentarzy opisywała i przedstawiała w niekorzystnym świetle pewne paradoksy edukacji zdalnej, np. paradoks dotyczący realizowania lekcji WF w trybie zdalnym: „pani przesyła im na początku lekcji link do youtube i dzieci mają obejrzeć jakiś filmik sportowy”; „pani na początku lekcji sprawdza obecność, a następnie sugeruje, by dzieci poszukały w sieci swoich ulubionych sportów i na nie popatrzyli"; „nauczyciel każdego dnia, kiedy jest WF, wysyła w dzienniku elektronicznym kartę pracy, w której dziecko ma zaznaczyć, że skakało, biegało”; „nauczyciel wysyła kartę "wyzwań « na cały tydzień i zalicza WF jak dziecko ją wypełni” , „muzyka polegała na przepisywaniu nut”, „wielokrotnym zapisie klucza wiolinowego” itp.

Zaledwie jednostki (6 osób) dostrzegły fakt, iż udział dziecka w lekcji powoduje jego radość i poczucie sprawstwa. Opinie te obejmują III kategorię wypowiedzi, tj. np. „dzieci grają na lekcjach on-line na flecie”; „... słuchają muzyki i rozmawiają o niej”, "pani rozmawia z dziećmi o ich ulubionej muzyce i przemyca muzykę klasyczną jako swoją ulubioną”, „pani opowiada o kompozytorach, to całkiem ciekawe, ponieważ robi prezentacje z dźwiękiem” itp.

\section{Wnioski i postulaty}

Biorąc pod uwagę przytoczone w tekście definicje dobrostanu psychicznego człowieka oraz dokonując analizy zebranego materiału empirycznego, nietrudno nie odnieść wrażenia, iż w czasie pandemii uczniowie nie mają poczucia wysokiej jakości funkcjonowania w sytuacji edukacji szkolnej. Brak odczuwania dobrostanu - według wielu rodziców - wynika przede wszystkim z niekonsekwencji w zakresie strategii gospodarowania czasem lekcyjnym przez różnych nauczycieli. Rodzice nie odpowiadali wprost na temat poczucia satysfakcji dzieci na okoliczność odnoszonych sukcesów szkolnych, jednak liczne wypowiedzi wskazywały na to, że satysfakcja ta nie jest w pełni osiągana.

Z wypowiedzi respondentów wynika także, że nauczyciele pracowali w sposób bardzo zróżnicowany pod względem zaangażowania w proces edukacji. Wśród pedagogów - zdaniem rodziców - byli tacy, którzy cenili kontakt synchroniczny z dzieckiem, jednak część nauczycieli otwarcie odrzucała taki model kształcenia, stosując najmniej wymagające od nich rozwiązania, a tym samym nie widząc twarzy uczniów, nie obserwując ich reakcji w różnych sytuacjach wychowawczych, „nie czując się w żaden sposób odpowiedzialnymi za podejmowanie opieki nad dziećmi”. Te zaś - jak wskazywali interlokutorzy - czuły się osamotnione, nie rozumiały, z czego wynikają różnice w sposobie odbywania przez nauczycieli lekcji. Rodzice otwarcie krytykowali realizację wychowawczej, opiekuńczej czy kompensacyjnej funkcji szkoły. 
Wydaje się, że fakt zaistnienia pandemii zweryfikował kompetencje, a także motywację do pracy wielu nauczycieli. Nauczanie zdalne przyczyniło się do weryfikacji sposobów postrzegania przez grono pedagogiczne osoby dziecka oraz dbałości o warsztat pracy na rzecz osiągania przez ucznia dobrostanu psychicznego. Czas pandemii ukazał także wyraźnie, że troska o ów dobrostan nie jest przedmiotem zaangażowania każdego nauczyciela, ale przede wszystkim wychowawcy klasy. Bardzo niepokojącym wnioskiem ogólnym jest taki, że wielu aktywnych zawodowo nauczycieli nie ma potrzeby bezpośredniego kontaktu z dzieckiem.

W wyniku analizy wypowiedzi rodziców można stwierdzić, że szkoła w pandemii nie sprzyja dobremu samopoczuciu dziecka, nie tworzy mu przyjaznego i wspierającego środowiska w kontekście naturalnych dziecięcych potrzeb. Jest to wniosek niezwykle niepokojący, ponieważ dziecko w dążeniu do poczucia szczęścia powinno mieć sprzyjające środowisko wychowawcze nie tylko w domu, lecz także w szkole, nawet jeśli szkoła ta funkcjonuje wyłącznie w internecie. Edukacja szkolna, jak trafnie zauważa Kazimierz Przyszczypkowski, „przypada w okresie kształtowania się poglądu na świat i poszukiwania sensu życia. Umysł młodego człowieka jest w tym okresie elastyczny i bardzo otwarty. Zamknięcie instytucjonalne edukacji i towarzyszące temu zamknięcie paradygmatyczne nie pozostaje bez wpływu na dalsze życie młodych ludzi, a w konsekwencji na rozwój kultury i cywilizacji” (Przyszczypkowski 2012: 19).

Podsumowując rozważania zawarte w niniejszym opracowaniu, można jednak, w związku z niekorzystnymi wynikami badań, przyjąć, że szkoła, podobnie jak społeczeństwo, znalazła się w nagłej, kryzysowej sytuacji globalnej pandemii, stanęła tym samym przed nieznanym jej dotąd i trudnym wyzwaniem. Należy zaznaczyć, że szkoła, tak jak my wszyscy, musiała zmierzyć się z nową rzeczywistością oraz dość szybko na rzeczywistość tę trafnie zareagować. Spoglądając na wyniki badań dotyczące przygotowania nauczycieli do kształcenia zdalnego, należy za Joanną Madalińską-Michalak dostrzec, iż wielu nauczycieli szybko podjęło wysiłek przełamania barier zdalnego kształcenia, jednak wielu z nich przyznaje, że osiągnęło warsztat pracy w drodze samokształcenia (Madalińska-Michalak 2020: 26). O ile w pierwszym okresie pandemii od marca do czerwca 2020 roku -

Uczniowie tkwili w chaosie edukacyjnym ponad trzy miesiące (...) sami borykali się z problemami technicznymi (brak odpowiedniej sieci, sprzętu), z drugiej strony dosyć mocno odczuli brak kompetencji cyfrowych nauczycieli i ich umiejętności dopasowania zajęć do możliwości, które daje przestrzeń wirtualna. Lekcje, jeśli były, odbywały się w sposób tradycyjny, taki, jaki proponuje się w klasie lekcyjnej. Wiele zajęć jednak się nie odbywało i uczniowie nie mieli kontaktu z nauczycielami. Ci wysyłali im zadania i materiały do samodzielnego przyswajania oraz zadawali zadania domowe i oceniali efekty ich samodzielnej pracy (Jagielska 2020: 113- 114), 
to:

nauczyciele oraz uczniowie w ciągu minionego roku zdobyli wiele doświadczeń związanych z szeroką pojętą edukacją zdalną, które z pewnością będą mogli wykorzystać w przyszłości (Plebańska, Szyller, Sieńczewska 2021: 73).

Polska szkoła, tak jak i współczesne, doświadczające rozprzestrzeniania się koronawirusa społeczeństwo, uczy się stopniowego funkcjonowania w nowych okolicznościach, i - choć być może w zbyt wolnym tempie - poszukuje rozwiązań sprzyjających poczuciu dobrostanu psychicznego dziecka. Poszukiwania te, w obliczu tak licznych obostrzeń, tragedii, krytycznych wydarzeń, są niewątpliwie ogromnym wyzwaniem.

\section{Bibliografia}

Chałas K. (2018). Edukacja aksjologiczna i wychowanie ku wartościom podstawa budowania szkoty jako wspólnoty życia, pracy i stużby, „Prima Educatione” nr 2, s. 11-22.

Chałas K. (2020). Przestrzenie aktywności nauczyciela akademickiego i studenta $w$ świetle dydaktyki zaangażowanej, „Studia Pedagogica Ignatiana”, nr 2, s. 111-127.

Cieślińska J. (2013). Poczucie dobrostanu i optymizmu życiowego kadry kierowniczej placówek oświatowych, „Studia Edukacyjne”, nr 27, s. 95-112.

Foucault M. (1998). Nadzorować i karać. Narodziny więzienia. Warszawa: Wydawnictwo Fundacji Aletheia.

Gawlicz K. (2008). Konstruowanie nieudacznika. Praktyki normalizacji i wykluczania w przedszkolu, „Zeszyty Etnologii Wrocławskiej”, nr 1(10), s. 37-54.

Ilska M., Kołodziej-Zaleska A. (2018). Dobrostan hedonistyczny $i$ eudajmonistyczny $w$ sytuacjach kryzysów normatywnych i nienormatywnych, „Zeszyty Naukowe Politechniki Śląskiej”, Seria: Organizacja i Zarządzanie, nr 123, s. 155-184.

Jagielska K. (2020). Edukacja zdalna w sytuacji pandemii w doświadczeniach uczniów szkót średnich [w:] Wyzwania dla edukacji w sytuacji pandemii COVID-19, red. N.G. Pikuła, K. Jagielska, J.M. Łukasik. Kraków: Scriptum, s. 95-118.

King L.A., Eells J.E., Burton C.M. (2007). Pojęcie dobrego życia - w ujęciu szerokim i waskim. [w:] Psychologia pozytywna w praktyce, red. P.A. Linley, S. Joseph. Warszawa: Wydawnictwo Naukowe PWN, s. 19-41.

Klus-Stańska D. (2010). Dydaktyka wobec chaosu pojęć i zdarzeń. Warszawa: Wydawnictwo Akademickie Żak.

Klus-Stańska D., Nowicka M. (2019). Sensy i bezsensy edukacji wczesnoszkolnej. Gdańsk: Harmonia.

Klus-Stańska D. (red.). (2015). (Anty)edukacja wczesnoszkolna. Kraków: Impuls.

Kossakowska K., Zadworna M. (2019). Wybrane aspekty dobrostanu psychicznego uczniów na różnych etapach edukacji. Doniesienia wstępne, „Studia Edukacyjne” nr 54, s. $221-235$. 
Madalińska-Michalak J. (2020). Nauczanie zdalne i edukacja nauczyciela-wyzwania, [w:] Wyzwania dla edukacji w sytuacji pandemii COVID-19, red. N.G. Pikuła, K. Jagielska, J.M. Łukasik. Kraków: Scriptum, s. 30-30.

Martin E. P. Seligman (1993). Optymizmu można się nauczyć. Poznań: Media Rodzina.

Plebańska M., Sieńczewska M., Szyller A. (2020) Raport-Edukacja zdalna w czasach COVID-19. Warszawa: Wydział Pedagogiczny Uniwersytetu Warszawskiego.

Plebańska M., Sieńczewska M., Szyller A. (2021) Co zmienito się w edukacji zdalnej podczas trwania pandemii? Raport zbadania. Marzec 2021. Warszawa: Wydział Pedagogiczny Uniwersytetu Warszawskiego.

Przyszczypkowski K. (2012). Polityczność (w) edukacji. Poznań: Wydawnictwo Naukowe UAM.

Surma B. (2019). Wprowadzenie, „Edukacja Elementarna w Teorii i Praktyce” nr 4 (54), t. 14, s. 7-8.

Seligman M.E.P.(2002). Authentic Happiness: Using the New Positive Psychology to Realize Your Potencjal for Lasting Fulfillment. New York: Free Press, Simon and Schuster.

Seligman M.E.P. (2011). Petnia życia. Nowe spojrzenie na kwestię szczęścia i dobrego życia. Poznań: Media Rodzina.

Śliwerski B. (2015). Edukacja (w)polityce. Polityka (w)edukacji. Kraków: Oficyna Wydawnicza Impuls.

Śliwerski B. (2007). Pedagogika dziecka. Studium pajdocentryzmu. Gdańsk: Pedagogika GWP.

Śliwerski B. (2009). Problemy wspótczesnej edukacji. Dekonstrukcja polityki oświatowej III $R P$. Warszawa: Wydawnictwo Akademickie i Profesjonalne.

Śliwerski B., Śliwerska W. (1991). Edukacja w wolności. Kraków: Oficyna Wydawnicza Impuls.

Trzebińska E. (2008). Psychologia pozytywna. Warszawa: Wydawnictwa Akademickie i Profesjonalne.

\section{ADRES DO KORESPONDENCJI}

Katarzyna Bożena Sadowska

Uniwersytet im. Adama Mickiewicza w Poznaniu

e-mail: kawka@amu.edu.pl 